\title{
Application Analysis on the "Pheromones" Methods of Legal Education Pedagogy
}

\author{
Shiyong Song \\ School of Humanities and Law \\ Qilu University of Technology \\ Ji'Nan, P. R. China, 250353 \\ e-mail: 13583157531@163.com
}

\begin{abstract}
Legal education has a particular value orientation. This value orientation to achieve, mainly as a social employer for graduates of law recognized. "Pheromones" type of legal education pedagogy, based on the interest of students to achieve goals and objectives. In the teaching process, teachers will use this to lure students in active learning. The teaching process is a reasonable accumulation and release of theoretical and practical knowledge of the teacher's own law. Teachers in the teaching process to fully mobilize the students to actively participate in awareness and enthusiasm, initiative to attract students to actively participate in the teaching process to achieve legal education should be valued, and ultimately the unity and integration of social benefits.
\end{abstract}

Keywords-Legal Education; Pheromones effect; Benefits realized; Teaching Methods; Social benefits

\section{INTRODUCTION}

Undertake the important task of legal education on training legal professionals, dissemination of legal knowledge, promote the spirit of the law, conservation laws and ethical, legal education is also an important channel for citizens to improve legal quality. A qualified legal professionals, judicial philosophy must have a high level of understanding, the law must be very proficient, basic values must consciously follow the law justice and conscience. Ignorant, incompetent, without virtue who have any of these conditions people are not engaged in the legal profession. In this sense, first, legal education, legal talent only after that. Professional Law teaching is an important means to achieve the goals and objectives of legal education. Rationality and feasibility of implementing ways of teaching methods directly affect the actual effectiveness of legal education. If we follow the innovative knowledge + ability + morality $=$ successful teaching general moral teaching law, teaching methods is crucial to achieve the educational goals of law.

The major of law is one of the most popular profession in
Higher Education of our country at present. From the vantage point, the number of students studying law is so much, explains that in the process of social development, People pay attention to the law, analysis from a negative perspective, graduate employment rate of law major students is so low, explains the serious mismatches between the actual demand of educational goals and social. [1]

According MyCOS Institute wrote "2012 China Graduate Employment Report" shows that law major at the 2011 session of all professional graduates six months after graduation employment rate survey, the employment rate is the lowest of the professional, but also the 2012 employment Red Warning regional specialty. Admittedly, this situation with the existing institutions of professional settings law too much, too messy, too many graduates have a certain relationship, but it also has a great relationship with the teaching methods and teaching guide legal education. If the law is too single teaching methods and old, teaching is compromised, will result in the student employment options too narrow and can not work or can not be good jobs. Solve the problem of rationality and effectiveness of teaching methods of law, is an innovative education model and solve the fundamental problem of employment.

\section{Stage of Development of China Education Model Law AND EVALUATION}

In China, about the law of professional education and training model, has gone through three stages of development:

The first period was practiced in the early days of the Soviet model. The basic process is the formation of specialized legal institutions, unified management, such as in 1949, the establishment of Beijing Central Academy of Political Science, and as a basis for the formation of the People's University of China in 1950, setting the Faculty of Law began to recruit students and to bear country Legal Education "workhorses" of functions to the people around the university teacher education, which was also held by the Soviet experts directly taught postgraduate courses, specialized training of senior educational personnel law. 
The second period was the beginning of reform and opening up the implementation of the civil law model. Prevailing legal education, a greater emphasis on comprehensive human development as the goal of education in the teaching mode, although breaking the confines of the Soviet model, but the impact of the Soviet model still in the Anglo-American model of education and training has not yet introduced, is actually a close to the German, the French model of civil law model. Education Model take many forms, eclectic variety of levels to nurture talent. If there is law in the form of education degree in education and academic education, the education level of law, there are secondary, tertiary, undergraduate, double degree to master's and doctoral levels, emphasizing the dominant teachers on teaching methods, students are being absorbed position, chalk and talk style of teaching methods in general, equal discussion-style teaching methods rare.

The third period was a mixed-mode after the 1990s. At this point, further development of the market economy, the rule of law strategy of gradual implementation, foreign exchange facilities, the Anglo-American system of vocational education and general education training model training mode gradually accepted the people, but the Soviet model and the continental model has not completely abandoned. Education Model specific performance of foreign integration, diversification. Taught by a combination of simple to teach and teaching, teaching from theory to combine theory and practice of teaching to the exchange and enclosed by the comparison to the combination of face-to-face with pure online teaching a combination of integrated direction. [2]

In fact, in my opinion, the division of the three periods has some truth, but not absolute. No matter which period did not change the status quo simply chalk and talk teaching of law. It has a great relationship with teachers and students mental laziness. Although the university law teachers today are trying a variety of clinics, case type, comparative and other teaching methods, its main purpose is to serve the theoretical lectures, role and social practice for application integration is minimal.

\section{VALUE ORIENTATION OF LEGAL EDUCATION}

Legal education is the process of knowledge management, the management in teaching stage, is aimed at students theoretical knowledge. In the social practice, such as enterprises, for business success, knowledge management is necessary. It need a support, that is their ideological education system. [3]

Teaching has reached a good teaching effect, one measure is to look at graduate student's ability to adapt to society and the social acceptability for graduate students. The above employment law graduates "red light" phenomenon has revealed to us the answer, regardless of our legal education through the development of a sound kind of cruel reality is that society does not recognize the outcome of legal education, employment difficulties led to the graduates. At the same time hinted to us that our teaching method is indeed a problem.

\section{A. Teaching methods of legal education defects and eficiencies}

Consolidated current legal education, and in the teaching methods, mainly for the following deficiencies:

1) Object of education and education targeting confusion. Our rich and varied educational levels and relatively perfect law. From specialist to have a $\mathrm{PhD}$, but in the actual teaching, college, undergraduate, master's three main levels of education targeting is unknown, but reflects the difference between education levels, and teaching methods and content fundamentally there is no difference, so graduate student's ability to adapt to society can only be reading more, the ability to be more socially acceptable low, because there are no outstanding capability advantages. Society needs people are remunerated according to their abilities, since education is high and low levels of the same capacity, or even the second, prefer low-level graduates. So that the whole community to form a vicious circle. In fact, this cycle link from the school's instructional design began, but ultimately reflected in the employment part of the community only. This is simply due to the drawbacks of teaching objectives and positioning the object of education caused confusion.

2) Single and outdated teaching methods. Although each university has been exploring practical teaching methods, there have been clinics, case type, multi-directional interactive teaching methods. But fundamentally, these forms are superficial, are formal teaching methods in order to complete the task of teaching and proposed this form can not deepen into the substance of the actual needs of the community method and the integration of the contents of this to complete the task of teaching the single purpose of teaching methods embodied in various forms, which we call the substance of the unity of teaching methods, which ultimately could not get rid of their old unity, of course, will not be accepted social practice.

\section{B. Values orientation education and teaching methods in law}

Value orientation refers to people of certain rules in the long-term value of the trade-offs of social activities, recognition and use. Reflected in the teaching methods of law, mainly in the following aspects of the value orientation:

1) Intersubjectivity teaching. Intersubjectivity is an ideological and political education in educational theory. In fact, in legal education should also be well implemented. Intersubjectivity, also known as sex between subject, refers to the teacher guide, student cooperation and participation. This teaching method can overcome the previous teacher-led, student Tangguan drawbacks of passive lectures to inspire students to participate actively, the formation of a good logical thinking ability. This is the basis of education and teaching methods in law.

2) Multi-directional interactive teaching. This teaching method is different from the previous teacher-led chalk and talk teaching methods, but also different from both teachers and students as the main two-way interactive teaching, mainly for 
teachers and each student as an individual subject with multidirectional interactive teaching. In this teaching method, the theory and practice of teaching content analysis of the case put forward by teachers are built on the basis of teachers as one of the guiding body, the questions about the theoretical issues and controversies, teachers and every student practical problems are equal body problem in a different show, while speculative, students can gradually found dead professional thinking, and form their own logical thinking, teachers can find the difference in time between their thinking and thinking of the students, and to discover the true teaching of difficult and hot, better to carry out teaching, achieve better teaching results.

3) Receive transformative teaching. The purpose of education is not only to allow students to understand, this is only a low level of education goals, based on cognitive and teachers but also by a certain method, so that students can identify with teaching content, this identity is not rote, but on the basis of accepted knowledge on the basics can be converted to their ability to reflect on teaching methods, teaching is transformed receiver. If a student just take good notes in class by the instructor talked about what, that this teaching can not be considered successful, we call it "teach him to fish"; If students can use their own language very well expressed in the afterschool and course content flexible use of such teaching is successful, we call it "teach him to fish."

4) Teaching training habits. The process of education, but also the process used to develop, including learning habits, professional thinking habits, habits and so on. The method used to develop teaching requires teachers not only train students in learning and memory style habits, but also focuses on students' professional thinking habits, professional behavior habits. If the first three teaching method is to train students the ability to utilize the knowledge of rigid habits teaching is focused on training students' spiritual power and soft power behavior of individual ability.

\section{IV. "Pheromones" TYPE OF LEGAL EDUCATION PEDAGOGY}

Regardless of the method, and ultimately only one purpose, that is to achieve good teaching results. Legal education To achieve the above four values, "pheromones" teaching method is indispensable.

\section{A. "Pheromones" principle}

"Pheromone" is our human and animal hormones secreted by a chemical substance with a strong volatility, it allows the same species among different individuals, while passing through the role of olfactory messages generated behavioral or physiological changes. This chemical substance secreted by the exocrine glands, small molecules can wind flowing again quickly spread through the air flow to go around. It is crucial for men and women in love, can attract each other. [4]

If we made good use of "pheromones" principle in the education and teaching of law, then we can be community college students and employers considered poles. Relative to students, universities and other entities representing different "pheromones" material, they also release force, trying to influence on students; relative to the employer community, the students and other subjects they are two different "pheromones" material, but also the simultaneous release of power, trying to use that individual units of social love. The final selection of students and community based, is to look at their attractiveness as "pheromones" substances released is large enough.

\section{B. Education Law in "pheromones" effect}

Education Law in "pheromones" effect is mainly reflected in the ultimate realization of the knowledge of the teachers themselves taught reasonable thickness and the degree of accumulation of these teaching methods expertise.

The author believes that to achieve the education and teaching of law in the "pheromones" effect, should focus on improving the following aspects:

1) Accumulation and release of teachers' reasonable theoretical and practical knowledge, which is the basis of the effect achieved. If the lack of teacher's own theoretical and practical knowledge accumulation, it will be difficult to achieve diversification and rationalization of teaching methods, "pheromones" effect will break the roots, not to achieve social teaching. Only accumulation is not enough, we must also require this accumulation is a certain depth, but also there is a reasonable release methods and strategies in the teaching content and methods of teaching embodied arrangements, mainly to teach the theory and practice of teaching time arrangements and training in the form of arrangements.

2) Mobilize the students to actively participate in awareness and enthusiasm, which is the key to achieve the effect. Students are learning the subject, even on teaching methods and then flexible, rich lectures again, if you can not mobilize students to actively participate in awareness and motivation, teaching effect is still minimal, which is now a common phenomenon that some classroom teachers lecture style funny, teachers became orator, rattle, and students were happy to do a good listener, laughing, class recall, and consequently did not learn. This way of teaching first single burst of enthusiasm for teaching effect and does not contribute to the final realization of the social effects.

Teachers can arrange for teachers and students in teaching programs in the classroom together as equal subjects, respectively, of the contents of each class of the division ahead of the class project as a "cooperative." This allows students to understand, once in the classroom, teachers should do what work, such as the focus of theoretical knowledge to explain and analyze, review and direct the discussion of typical cases; students what work should be done, such as rehearsal and memory before class basic knowledge of (because the students master the knowledge of these points may be completed entirely by self), for example focusing on classroom knowledge analysis, mutual classroom debate difficult cases. 
Overall a principle, so that students truly feel the teachers and their teaching content integration for the atmosphere, not to feel both the upper and lower body position, through the concept of "cooperative projects", each play to their strengths together to achieve the same goal. When necessary, especially at the beginning of the implementation, the teacher can play a mandatory, to help students overcome their inertia, over time develop a good habit, it will later form the habit of teaching, the effect is significant.

3) Summary of actual legal business research needs of the community, targeted reflected in the teaching process, which is the ultimate requirement to achieve the effect.

Target of legal education has two levels: first, to enable students to master certain knowledge of the law, to become a qualified law graduates; second is to equip students with certain legal skills to become a qualified social worker. The first level is the primary goal of legal education, mainly at the various universities basically this , basically can achieve. The second level is the high-level goals of legal education, which is currently short board majority of university legal education , although many universities have noticed this short board and started some action, but the actual effect is yet to be proven, if direction of corporate legal practice carried out in university teaching, and some community legal services to carry out the direction of teaching universities, etc., are to carry out the work of law school education for the special needs of the community, it should be said that this is a welcome change in legal education, shows that our legal education and practice has started getting closer, the effect of education is also reflected in the employment benefits will be more prominent. But generally this is a problem existing targeted education to establish whether there is a rational behavior on the basis of universal research made or to highlight the characteristics of the so-called leadership racking our brains to come up with an impulse decision, if it is the former, ultimately reflected in employment, it should be brought to school graduates and good social reality; If the latter, the harsh reality will make the school a few years later and graduates are not teaching and employment characteristics of the real butt of embarrassment. Therefore, I believe that summarize the professional requirements of professional education employment from export demand, is an important part of teaching law pheromone formula method, because in this way associated with the vital interests of the students, when they learn that they are now the content and skills learned that the actual needs of the community core requirements, the reality of this interest -driven, self-conscious students will participate in a far greater degree of feedback on the final student teaching and social effects of employment, there will be a perfect value reflected.

\section{CONCLUSION}

Education law, there is a specific value orientation, the orientation of the ultimate realization of value requires teaching methods and content support, the key is to have a reasonable and practical teaching methods. "Pheromones" type of legal education pedagogy, student-centered, depending on the needs of the community to implement targeted teaching: For most students that graduate employment is concerned, according to the actual needs of the school community employers, application of countermeasures implemented teaching; hope for postgraduate studies in graduate students, taught by the school in the normal course, the combination of social status and lack of practice, the implementation of development, multidimensional interactive speculative training to teaching. In short, these two teaching methods are based on the vital interests of the student teaching lure starting point, to stimulate students' active participation in the initiative, to achieve the stated goals of teaching, which is the rationale of "pheromones" type of legal education pedagogy, for the law the actual needs of education to serve the community with critical positive.

\section{REFERENCES}

[1] Song shiyong: "Research on Open Experimental Teaching Method of Law", Proceedings of the Sixth International Symposium_Education Innovation and Dunhuang Culture Engineering, 2012, NO:354。

[2] Xu Xianming Editor : "Chinese education in Law", China University of Political Science and Law Press, 2006, No:70-80

[3] Song shiyong: "A Perfect Enterprise Ideological Education System : Foundation of Successful Knowledge Management",Proceedings of the $3^{\text {rd }}$ International Conference on Product Innovation Management, Hubei people's Publishing House, 2008, No:313.

[4] Tangning, "scientists have developed a love potion: pheromones through the sense of smell to enhance the attractiveness." China Network, Query time: 19 June 2012. 